\title{
QUALITY OF LANDRACE PIG LIQUID SEMEN DURING THE COLD SAVE PROCESS USING BTS AND TRIS AMINOMETHANE / DILUENTS EGG YOLK $20 \%$ ON $2-5^{\circ} \mathrm{C}$
}

\author{
Feka Wolfhardus Vinansius ${ }^{\star}$, Postgraduate Student \\ Isniani Nurul, Susilawati Trinil, Lecturers \\ Faculty of Animal Husbandry, University of Brawijaya, Malang, Indonesia \\ *E-mail: wolfhardusfeka@gmail.com
}

\begin{abstract}
Landrace pigs are often found in East Nusa Tenggara, which can fulfill the community's protein needs and Artificial Insemination can be used to improve the genetic quality of pigs. The aim of this study was to determine the shelf life of the quality of the spermatozoa of Landrace pigs using BTS thinners and tris aminomethane + egg yolk $20 \%$. This research was conducted at the University of Timor Agriculture Faculty Laboratory using Landrace pig semen. The research method was laboratory experiments using 2 treatments with 10 replications, namely T1 (BTS) and T2 (Tris Aminomethan + egg yolk 20\%) which were stored at refrigerator temperature $2-5^{\circ} \mathrm{C}$. The variables observed were individual motility and total motile spermatozoa. Data were analyzed using Randomized Block Design (RBD). The percentage of motility and total motile sperm were tested using Pearson's Chi Square with an expected value of 40 million motile sperm $/ \mathrm{ml}$. The results showed that the length of storage for the 3 hours of thinners did not have a significant effect $(P>0.05)$ while the storage time for the 6th hour, 9th hour, 24.48 and 72 percent motility of $\mathrm{T} 1$ individuals with $66.5 \%, 61.5 \%$, $52.5 \%, 42.5 \%, 32 \%$ were significantly different $(P<0.05)$ towards and T2 was $63 \%, 57 \%$ $47 \%, 37 \%, 22.5 \%$. The conclusion of this study is that BTS thinners have the ability to maintain the percentage of individual motility longer than Tris Aminomethane + egg yolk $20 \%$.
\end{abstract}

\section{KEY WORDS}

Liquid semen, landrace pig, individual motility, total motile spermatozoa, beltsville thawing solution.

Pigs are one of the meat producing commodities that have great potential to be developed, this is because pigs have beneficial traits and abilities including rapid growth, high litter size and good ration efficiency (75-80\%) and the percentage of carcass high (65$80 \%$ ) with cuts made at 12 months of age (Aberle et al. 2001).

Increased productivity of livestock in Indonesia has been carried out by applying livestock reproduction biotechnology through Artificial Insemination (Al) techniques to improve genetic quality (Susilawati, 2013). The use of frozen semen for certain areas has limited constraints of liquid nitrogen. One alternative to overcome this obstacle is by using liquid semen for Al. Liquid semen has many advantages such as easier manufacturing techniques and lower costs (Zaenuri et al., 2014). Making liquid semen also requires diluents that have easy and inexpensive conditions and are able to provide nutrients as an energy source for spermatozoa (Susilawati, 2011).

BTS diluents are currently the most used by Al farmers because of their affordable price and satisfying results. The results of the study of Kadirvel et al. (2005) showed that BTS could be used as a thinner for pig semen with a shelf life of 4 days at $17^{\circ} \mathrm{C}$, with motility at the 4th day observation reaching $64.43 \%$. Another study by Kommisrud et al. (2002) stated that using BTS thinners for 6 hours of storage at $16-18^{\circ} \mathrm{C}$ showed a percentage of $79.8 \%$ spermatozoa motility.

Tris Aminomethane thinner is one of the most widely used semen diluents. Its use is often combined with egg yolk. The results of a study by Yohana, Ducha, Rahardjo (2014) showed that egg yolk tris aminomethane thinners were able to maintain the quality of cow semen (motility, viability, spermatozoa abnormality) because of the complete composition. 
Costa et al. (2016a) revealed that Tris aminomethane $+20 \%$ egg yolk diluent was better than CEP- $2+10 \%$ yolk base diluent in the treatment of motility, viability and sperm crossing of ongole abnormalities for 7 days during the cooling process.

The Da Costa et al. (2016b) study showed that liquid semen stored for 1 and 5 days after dilution with tris aminomethane $+20 \%$ diluent egg yolk produced conception rate (CR) was $86.67 \%$ and $83.33 \%$, while service per conception (S / C) are 1.31 and 1.44 .

Based on the background and thinking above, this study was conducted to test individual motility and total pig semen semen motile spermatozoa using BTS thinners and tris aminomethane $+20 \%$ egg yolk stored at a temperature of $2-5^{\circ} \mathrm{C}$ to determine the shelf life of semen liquid Landrace pig and can be used in the process of artificial insemination ( $\mathrm{Al}$ ).

\section{MATERIALS AND METHODS OF RESEARCH}

The research was carried out at the Laboratory of the Faculty of Agriculture, University of Timor, Kefamenanu City Subdistrict, North Timor Tengah Regency, East Nusa Tenggara Province from September to October 2018. The material used in this research was semen from the 3 (three) Landrace pig studs with 3 years old and $270 \mathrm{~kg}$ pig weight using dummy (artificial parent). Semen used in this study had motility criteria for ++ period and individual motility $\geq 70 \%$. Egg yolks come from laying chicken eggs that are still new (egg age less than 3 days).

Semen from the reservoir is tested macroscopically and microscopically. Macroscopic tests include volume, color, consistency and $\mathrm{pH}$. Microscopic tests include concentration, motility, viability, abnormalities and membrane integrity of the spermatozoa.

This research method is a laboratory experiment with experimental design in this study using the Randomized Block Design (RBD) method with 2 treatments with 10 replications as a group. The treatments carried out were BTS and Tris Aminomethae $+20 \%$ egg yolk diluents stored in a refrigerator with a temperature of $2-5^{\circ} \mathrm{C}$. Observations were made after storing the 3rd, 6th, 9th, 24th, 48th and 72nd hours.

Making BTS Diluents. The basic diluent used is a diluent ready to use BTS $₫$. Making diluents begins with weighing $5 \mathrm{~g}$ of BTS powder and inserted into an Erlenmeyer glass, adding aquabides $100 \mathrm{ml}$ then homogenizing the mixture for minutes until homogeneous, and stored at a waterbath at $37^{\circ} \mathrm{C}$ after semen is collected.

Making Amimoethane Tris + Egg Yolk 20\% Diluent. Beginning with mixing tris aminomethane, citric acid, lactose and fructose in the Erlenmeyer tube. Add $80 \mathrm{ml}$ of distilled water and homogenize using a stirrer for 10-15 minutes. After being homogenized, then put it in a pan and heated to boiling for the purpose of sterilization. The temperature is reduced from $100^{\circ} \mathrm{C}$ to $37^{\circ} \mathrm{C}$. Add penicillin and streptomycin antibiotics and homogenize for $10-15$ minutes. Put the mixture in the refrigerator until the third day, separated from the supernatant and the sediment, the results of the supernatant are ready for use. $20 \%$ yolk is added after the diluent is used (Susilawati, 2011).

The variables observed in this study were the quality of sperm from diluted landrace pig semen, including:

1. Individual mobility. One drop of semen was taken using an ose and placed on the glass of the object and covered with a glass cover then observed with a light microscope at 400x magnification (Susilawati, 2013; Ax et al., 2008).

2. Total motile spermatozoa. Total motile spermatozoa is the multiplication of semen volume with spermatozoa concentration and percentage of progressive motile spermatozoa (Susilawati, 2013).

Data from the results of the study were analyzed using variance analysis in Randomized Block Design (RBD) grouped by replication (shelter time). If there is a significant difference followed by a multiple distance test (Duncan). Total motile spermatozoa were tested with Pearson's Chi Square with an expected value of 40 million motile spermatozoa / $\mathrm{ml}$. While the percentage of motile spermatozoa with an expected value of $40 \%$ to ensure that semen is still suitable for use in Al according to SNI. 


\section{RESULTS AND DISCUSSION}

Semen Examination. The average value that evaluates semen from this study can be seen in Table 1.

Table 1 - Results of Semen Examination

\begin{tabular}{|c|c|}
\hline Color & Yellowish white \\
\hline Smell & Typical \\
\hline Consistency & Liquid \\
\hline Ph & $7.0 \pm 0.0$ \\
\hline Volume $(\mathrm{ml})$ & $221 \pm 25.14$ \\
\hline Concentration $\left(10^{6} / \mathrm{ml}\right)$ & $188 \pm 53.01$ \\
\hline Mass motility & ++ \\
\hline Individual Motility $(\%)$ & $74 \pm 2.10$ \\
\hline
\end{tabular}

In Table 1 shows that the results of the macroscopic examination of the average volume of Landrace pig semen produced by the study were $221 \pm 25.14 \mathrm{ml}$ per ejaculate in the range of $190-260 \mathrm{ml}$. The volume of Landrace pig semen produced in the study shows the normal range. In line with Sumardani et al., (2008) stated that the volume of fresh semen of pigs ranges from 150-250 $\mathrm{ml}$ per ejaculation. Measuring the volume of pig semen is done by looking at the scale on the tube used.

Observation of the color and smell of fresh pork semen is carried out during the shelter. The color and smell of the Landrace pig semen observed by the study showed that the fresh semen of Landrace pork was yellowish white (creamy) and distinctive. The color and smell of fresh semen produced shows that the condition of semen is included in the good category, not contaminated with blood, pus, urine or other contaminating substances. The degree of acidity or $\mathrm{pH}$ of Landrace pig semen during the study of ten constant shelters, i.e. an average of $7.0 \pm 0.0$ with liquid consistency. Fresh semen has a $\mathrm{pH}$ of 7 can be said normal because this result is in accordance with that stated by Bearden et al (2004), Garner and Hafez (2008) that the average $\mathrm{pH}$ of semen that is normal is 6.8-7.8.

Observation data in the study obtained the value of mass motility (mass movement) is ++ . The motility of spermatozoa mass is categorized into 3 groups, namely spermatozoa mass movements resembling thick and fast moving clouds (+++), spermatozoa mass movements resembling thick clouds and moving rather slowly $(++)$ and spermatozoa movements resembling thin clouds and slow moving (+) (+) (Richard et al., 2016). The average value of mass motility from the results of the study shows the level of activity of the movement of the spermatozoa is classified as moderate.

The results of the microscopic test of the quality of liquid Pig Landrace semen obtained an average motility of $74 \pm 2.10 \%$. Individual motility presentations of the results of the study were classified as normal spermatozoa motility i.e. 50-80\% (Garner and Hafez 2000). Factors that can affect the motility of spermatozoa in pigs are age, genetics, livestock, environment and feed. The percentage of motility in this study is relatively high, this is meant so that the spermatozoa used are more able to survive during the storage process. The average concentration of fresh spermatozoa obtained was $188 \pm 53.01$ (106/ ml). This result is the same as Sumardani (2008): Johnson et al. (2000); Gadea (2003); Robert (2006) which is $191.65 \pm 71.1(106 / \mathrm{ml})$.

Percentage of Individual Motilita. The mean and SD values of spermatozoa motility in this study during storage at $2-5^{\circ} \mathrm{C}$ can be seen in Table 2 .

The results of variance analysis showed that the length of storage of the 3 hours of diluent did not significantly affect $(P>0.05)$ the motility of the spermatozoa of Landrace pigs. This is presumably because at the 3rd hour the diluent still provides the same protection against the motility of the spermatozoa. Whereas Duncan Test results showed that the value of motility at the time of storage of hours to 6, 9, 24, 48 and 72 in treatment T1 (control) was $66.5 \%, 61.5 \%, 52.5 \%, 42.5 \%, 32 \%$ significantly different $(\mathrm{P}<0.05)$ against and $\mathrm{T} 2$ by $63 \%$, $57 \% 47 \%, 37 \%, 22.5 \%$. T1 thinner (BTS) produced the highest motility of individual spermatozoa at cold storing hours of hours 3, 9, 24, 48 and 72 . This is because BTS thinners 
are more suitable in maintaining quality (individual motility, viability, normal shape and membrane integrity) of pig spermatozoa during storing cold.

Table 2 - Percentage of Motility of Spermatozoa of Landrace Pigs at $2-5^{\circ} \mathrm{C}$

\begin{tabular}{lll}
\hline Hour & Treatment & Individual Motility (\%) \\
\hline 3 & T1 & $69 \pm 2.11^{\mathrm{a}}$ \\
& T2 & $69 \pm 2.11^{\mathrm{a}}$ \\
\hline 6 & T1 & $66.5 \pm 3.37^{\mathrm{b}}$ \\
& T2 & $63 \pm 2.58^{\mathrm{a}}$ \\
\hline 9 & T1 & $61.5 \pm 3.37^{\mathrm{b}}$ \\
& T2 & $57 \pm 2.58^{\mathrm{a}}$ \\
\hline 24 & T1 & $52.5 \pm 2.64^{\mathrm{b}}$ \\
& T2 & $47 \pm 2.68^{\mathrm{a}}$ \\
\hline 48 & T1 & $42.5 \pm 2.64^{\mathrm{b}}$ \\
& T2 & $37 \pm 2.58^{\mathrm{a}}$ \\
\hline 72 & T1 & $32 \pm 3.5^{\mathrm{b}}$ \\
& T2 & $22.5 \pm 2.64^{\mathrm{a}}$ \\
\hline
\end{tabular}

Note: T1 (BTS) and T2 (Tris Aminomethan + KT 20\%); *) Different superscript in rows shows significant difference $(P<0.05)$.

The results of variance analysis show that the longer the storage time the percentage of motility decreases. Membrane damage can cause ATP production to stop and the spermatozoa cannot move. This is in accordance with the statement of Zega et al. (2015) that diluents used to store semen are still needed macromolecules such as egg yolk which function to protect the spermatozoa during storage. Decreasing the percentage of spermatozoa motility during storage is due to the reduced energy reserves of spermatozoa to move (Nugroho et al., 2014).

According to the Indonesian National Standard (SNI) No. 8034 in 2014 regarding pig liquid semen, pig liquid semen that has been preserved must show spermatozoa motility of at least $40 \%$ and the movement of spermatozoa individuals with a minimum score of 2 (two). Based on Table 2. Above the average percentage of spermatozoa motility during the study of the use of BTS diluents during storage at refrigerator temperatures $2-5^{\circ} \mathrm{C}$ until the 48 th hour still had motility in the SNI standard so that it could be used for artificial insemination (> $40 \%$ ). While Tris Aminomethan + egg yolk $20 \%$ thinner average motility above $40 \%$ is only obtained at 24 hours after storage treatment.

Pearson's Chi Square test results with the expected value of the percentage of motility at $40 \%$ at 48 hours $\mathrm{T} 1$ diluent were not significantly different $(P>0.05)$ indicating that the T1 thinner at $2-5^{\circ} \mathrm{C}$ can still be used for Al until the storage time 48th hour. Whereas at the 24hour storage time T2 thinners were not significantly different $(P>0.05)$ which was stored at 2$5^{\circ} \mathrm{C}$ can be used for Al until the 24th hour saving time because total motile spermatozoa was not significantly different from the expected value of 40 million spermatozoa / $\mathrm{ml}$.

Total Spermatozoa Motil. The effectiveness of the success of artificial insemination is determined also by the total motile spermatozoa and spermatozoa morphology (Nikbakht and Saharkhiz, 2011). Total motile spermatozoa were calculated by semen volume multiplied by the concentration of spermatozoa with the percentage of individual motility (Susilawati, 2013). The total calculation of motile spermatozoa in the BTS thinner treatment, Tris Aminomethan + KT $20 \%$ can be seen in Table 3 .

Table 3 - Total Spermatozoa Motil Pig Landrace on Save Time 24th and 48th hours

\begin{tabular}{|c|c|c|}
\hline \multirow{2}{*}{ Thinner Treatment } & \multicolumn{2}{|c|}{ Total motile spermatozoa (million / ml) } \\
\cline { 2 - 3 } & 24 Hour & 48 Hour \\
\hline T1 & - & 42.5 \\
\hline T2 & 47 & - \\
\hline Expectation Value & \multicolumn{2}{|c|}{40.00} \\
\hline
\end{tabular}

The results of the analysis using Pearson's Chi Square with an expected value of 40 million motile spermatozoa per 100 million concentrations at 48 hours of storage for T1 were 
not significantly different $(P>0.05)$. Equally for the $T 2$ treatment at the 24th hour shelf life $(P>$ 0.05).

This means that liquid semen using T1 diluents can still be used for IA until the 48th hour saving time because the total motile spermatozoa is not significantly different from the expected value of 40 million spermatozoa / ml, while the liquid semen uses T2 thinners stored at $2-50 \mathrm{C}$ can be used for IA until the 24th hour saving time.

\section{CONCLUSION AND RECOMMENDATIONS}

The best thinners in maintaining the quality of the Landrace pig semen at a temperature of $2-5^{\circ} \mathrm{C}$ are BTS thinners which have the highest percentage of motility compared to Tris Aminomethan thinners $+20 \%$ egg yolk. The results showed that BTS thinners can be stored for 48 hours while Tris Aminomethane + KT 20\% diluents can be stored for 24 hours with a minimum spermatozoa motility of $40 \%$ according to the Indonesian National Standard (SNI) No. 8034 of 2014 regarding the use of preserved Landrace pig liquid semen must show spermatozoa motility of at least $40 \%$.

It is recommended that the use of Landrace pig semen for IA purposes using BTS thinners should be stored for 48 hours while the Tris Aminomethane $+20 \%$ Egg Yolk diluent is stored for 24 hours.

\section{ACKNOWLEGEMENTS}

We thank you to the management of the University of Timor's Faculty of Agriculture Laboratory for supporting research by providing research locations and materials.

\section{REFERENCES}

1. Aberle ED, Forrest JC, Gerrard DE, Mills EW. 2001. Principles of Meat Science. Ed ke-4. lowa (USA): Kendall/Hunt Publishing Company.

2. Ax , R.L. M. Dally, B.A. Didion, R.W. Lenz, C.C. Loce, D.D. Varner, B. Hafez, and M.E. Bellin, 2008. Semen Evaluation in farm Animal Reproduction ed By Hafez ESE. $7^{\text {th }}$ Lea Febiger: 365-375

3. Bearden, H.J. and W. Fuquay. 2000. Applied Animal Reproduction 5th Ed. Prentice Hall. UpperSaddle river. New Jersey

4. Da Costa, N., Susilawati, T., Isnaini, N. and Ihsan, M.N. 2016a. Effect of different dilution materials usage on Indonesian Peranakan Ongole bull sperm quality during cooling process. Indo American Journal of Pharmaceutical Sciences (IAJPS). 3 (4): 379385 ISSN 2349-7750Available online at: http:// www.iajps.com

5. Da Costa, N., Susilawati, T., Isnaini, N. and Ihsan, M.N. 2016b. The difference of artificial insemination successful rate of Ongole filial cattle using cold semen with different sturage time with Tris aminomethan egg dilution agent. ISOR Journal of Pharmacy. 6 (6): 13-19. ISSN: 2319-4219. www.isorphr.org

6. Gadea, J. 2003. Semen extenders used in the artificial insemination of swine. Spanish J. Of Agric. Research 1:17-27.

7. Hafez, E.S.E. 2008. Preservation and Cryoprsevation of Gamets and Embryos In B. Hafez and E.S.E Hafez (ed). Reproduction in Farm Animals. $7^{\text {th }}$ edition. Lippincott Wiliams. Philadelphia. ISBN 0-683-30577-8: 431-442

8. Johnson, L.A., K.F. Weitze, P. Fiser and W.M.C.Maxwell. 2000. Storage of boar semen. J Anim Sci 62: 143-172.

9. Kadirvel G, Nasker S, Das A, Hasin D. 2005. Effect of different extenders on preservation of boar semen at $17{ }^{\circ} \mathrm{C}$ [abstrack]. Di dalam: Gadella B.M \& Colenbrander B, editor. Proceedings of the V International Conference on Boar Semen Preservation; 2003 Agt 24-27; Doorwerth, The Netherlands. Theriogenology. 63: 685-692. 
10. Kommisrud E, Paulenz H, Sehested E, Grevle I.S. 2002. Influence of boar and semen parameter on motility and acrosome integrity in liquid boar semen stored for five days. Acta Vet Scand. 43(1):49-55.

11. Nikbakht, R., Saharkhiz. 2011. Influence of Sperm Morphology, Total Motile Sperm Count of Semen and Number of Motile Sperm Inseminated in Sperm Samples on the Success of Intrauterine Insemination. International Journal of Fertility and Sterility 5 (3): 168-173.

12. Robert, V.K. 2006. Semen processing. Extending \& Storage for Artificial Insemination in Swine.Dept.of Animal Science University of Illinois.

13. [SNI] Standar Nasional Indonesia. 2014. SNI 8034:2014 Tentang Semen Cair Babi. Jakarta (ID). Badan Standardisasi Nasional.

14. Sumardani NLG., LY. Tuty, PH. Siagian, 2008. Viabilitas Spermatozoa Babi Dalam Pengencer BTS (Beltsville Thawing Solution) yang Dimodifikasi pada Penyimpanan Berbeda. Media Petern. 31: 81-86.

15. Susilawati, T. 2011. Spermatology. Universitas Brawijaya Pres. Malang. ISBN: 978-6028960-04-05

16. Susilawati, T. 2013. Pedoman Inseminasi Buatan Pada Ternak. Universitas Brawijaya Pres. Malang. ISBN: 978-602-203-458-2

17. Yohana T., N. Ducha and Rahardjo. 2014. Pengaruh Pengencer Sintetis and Alami Terhadap Motilitas Spermatozoa Sapi Brahman Selama Penyimpanan dalam Suhu Dingin. Lentera Bio 3 (3): 261-265.

18. Zaenuri L.A., Susilawati T., Wahyuningsih S., \& Sumitro S.B. (2014). Preservation Effect of Crude Fig Fruit Filtrate (Ficus carica L) Added In to Tris Egg Yolk Based Extender on Capacitating, Acrosome and Fertility of Half Blood Boer Buck Spermatozoa. IOSR Journal of Agriculture and Veterinary Science, 7(5), 60-68.

19.Zega, I., S. Ilyas and S. Hutahaean. 2015. Kualitas Sapi Limousin dalam Pengencer Two-Stetm Extender dengan Suplementasi Kuning Telur Bebek Selama Penyimpanan pada Refigerator. Jurnal Biosains 1 (3): 66-72. 